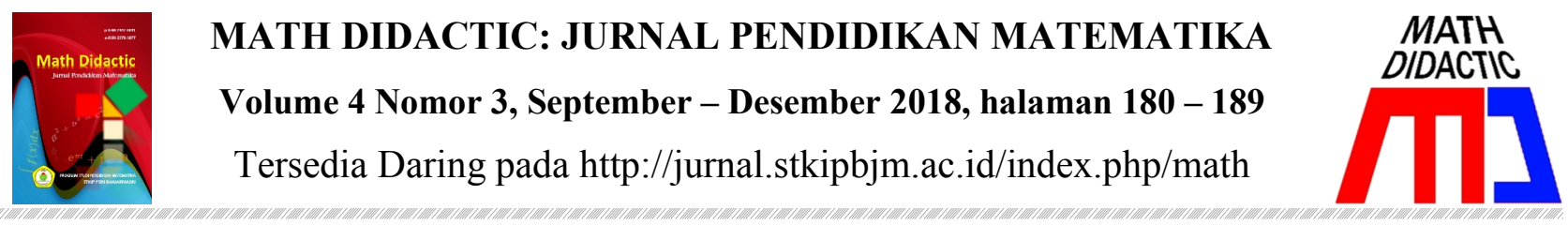

\title{
PROSES BERPIKIR SISWA DALAM MENYELESAIKAN MASALAH BARISAN DAN DERET ARITMATIKA
}

\section{STUDENTS THINKING PROCESS IN SOLVING ARITHMETIC SEQUENCE AND SERIES PROBLEMS}

\author{
Anggita Febriliyani, Novisita Ratu \\ Program Studi Pendidikan Matematika FKIP Universitas Kristen Satya Wacana \\ 202015072@student.uksw.edu,novisita.ratu@staff.uksw.edu
}

\begin{abstract}
Abstrak: Jenis penelitian ini adalah deskriptif kualitatif yang bertujuan untuk menganalisis proses berpikir siswa dalam menyelesaikan masalah barisan dan deret aritmatika. Subjek dalam penelitian ini 3 siswa kelas XII SMA Negeri 1 Ambarawa tahun pelajaran 2018/2019 yaitu FHA sebagai subjek kemampuan tinggi, AK sebagai subjek kemampuan sedang dan WDR sebagai subjek kemampuan rendah. Metode pengumpulan data pada penelitian ini adalah tes, wawancara, dan dokumentasi. Hasil penelitian menunjukkan bahwa dalam menyelesaikan soal nomor 1 materi barisan aritmatika semua subjek menggunakan proses berpikir konseptual sedangkan dalam menyelesaikan soal nomor 2 materi deret aritmatika subjek tinggi menggunakan proses berpikir konseptual dan subjek sedang dan rendah menggunakan proses berpikir semikonseptual.
\end{abstract}

Kata Kunci: proses berpikir, barisan dan deret aritmatika

\begin{abstract}
: this research is a qualitative descriptive which aims to analyze students thinking process in solving arithmetic sequence and series problems. Subject in this research were three grade XII students of SMA Negeri 1 Ambarawa on of academe year 2018/2019 is FHA as a high ability subject, AK as a medium ability subject, and WDR as a low ability subject. Data collecting methods are test, interview, and documentation. The result showed that in solving arithmetic sequence the first number problem all subjects used the conceptual thinking process while the second number arithmetic series problem the high subject used the conceptual thinking process and the medium and low subject used the process of using semiconceptual.
\end{abstract}

Keywords: thinking process, arithmetic sequence and series

Cara Sitasi: Febriliyani, A. \& Ratu, N. (2018). Proses berpikir siswa dalam menyelesaikan masalah barisan dan deret aritmatika. Math Didactic: Jurnal Pendidikan Matematika, 4(3), 180-189. 
Matematika adalah suatu ilmu yang memiliki objek tujuan abstrak, bertumpu pada kesepakatan dan pola pikir deduktif (Soejadi, 2000, hal.11). Salah satu tujuan pembelajaran matematika di sekolah adalah melatih cara berpikir dan menalar dalam menarik kesimpulan (Siswono, 2002, hal.24). Hal itu terdapat pada kurikulum di Indonesia yang mengatur bahwa mata pelajaran matematika perlu diberikan guna membekali siswa dengan kemampuan berpikir, logis, analitis, sistematis, kritis, dan kreatif serta kemampuan kerja sama. Proses pembelajaran matematika tak lepas dari seorang guru atau pendidik. Menurut Steiner dan Cohor-Fresenborg (dalam Mirza, 2008, hal.73) bahwa tugas pokok pendidik matematika adalah menjelaskan proses berpikir siswa dalam mempelajari matematika dengan tujuan memperbaiki pengajaran matematika di sekolah.

Proses berpikir adalah penerimaan informasi yang kemudian dari informasi tersebut diolah untuk dicari kesimpulannya dan kesimpulan tersebut bisa dipanggil kembali dari informasi yang telah didapat tadi bila diperlukan (Eka, 2008, hal.22). Pada dasarnya setiap individu memiliki proses berpikir yang berbeda dengan yang lain (Tayler dalam Sunaryo, 2011, hal. 20). Zuhri (2008) mengungkapkan bahwa proses berpikir dibagi menjadi 3 yaitu konseptual, semikonseptual, dan komputasional.

Proses berpikir konseptual adalah cara berpikir seseorang dalam menyelesaikan masalah dengan menggunakan konsep yang telah dimiliki berdasarkan hasil pembelajarannya selama ini, adapun indikatornya yaitu (1) mampu mengungkapkan dengan kalimat sendiri tentang hal yang di ketahui dalam soal, (2) mampu mengungkapkan dengan kalimat sendiri tentang hal yang di tanya dalam soal, (3) mampu menjelaskan ide penyelesaian masalah dengan jelas, (4) dalam menjawab soal cenderung menggunakan konsep yang sudah dipelajari, dan (5) mampu mengungkapkan langkah-langkah yang ditempuh dalam menyelesaikan soal. Proses berpikir semikonseptual adalah cara berpikir seseorang dalam menyelesaikan masalah menggunakan konsep tetapi pemahamannya terhadap konsep tersebut belum lengkap sehingga penyelesaiannya dicampur dengan menggunakan intuisi, adapun indikatornya yaitu (1) kurang mampu mengungkapkan dengan kalimat sendiri tentang hal yang di ketahui dalam soal, (2) kurang mampu mengungkapkan dengan kalimat sendiri tentang hal yang di tanya dalam soal, (3) kurang mampu menjelaskan ide penyelesaian masalah dengan jelas, (4) dalam menjawab soal cenderung menggunakan konsep yang sudah dipelajari walaupun tidak lengkap, dan (5) tidak sepenuhnya mengungkapkan langkah-langkah yang ditempuh dalam menyelesaikan soal. Sedangkan proses berpikir komputasional adalah cara berpikir seseorang dalam menyelesaikan masalah tidak menggunakan konsep tetapi lebih mengandalkan intuisi, adapun indikatornya yaitu (1) tidak mampu mengungkapkan dengan kalimat sendiri tentang hal yang di ketahui dalam soal, (2) tidak mampu mengungkapkan dengan kalimat sendiri tentang hal yang di tanya dalam soal, (3) tidak mampu menjelaskan ide penyelesaian masalah dengan jelas, (4) dalam menjawab soal cenderung lepas dari konsep yang sudah dipelajari, dan (5) tidak mampu mengungkapkan langkah-langkah yang ditempuh dalam menyelesaikan soal.

Berdasarkan pengalaman peneliti pada saat magang, siswa masih merasa kebingungan dengan materi barisan dan deret 
aritmatika dalam bentuk soal cerita, oleh karena itu akan dilakukan penelitian pada materi barisan dan deret aritmatika. Materi barisan dan deret aritmatika merupakan materi yang diuji dalam setiap tes masuk perguruan tinggi maupun dalam melamar pekerjaan. Saat dilakukan tes untuk materi barisan dan deret aritmatika, siswa masih mengalami permasalahan pada cara mengubah kalimat kedalam model matematika (lihat pada gambar 1). Hal ini sependapat dengan penelitian Khasanah dan Sutama (2015) yang menyimpulkan bahwa siswa tidak dapat mengidentifiksikan/menuliskan apa yang diketahui dan dicari, ketidakmampuan siswa mentransformasikan kalimat ke dalam model matematika, dan kurangnya penguasaan konsep yang diterapkan sehingga siswa sulit menentukan rumus/strategi yang digunakan.

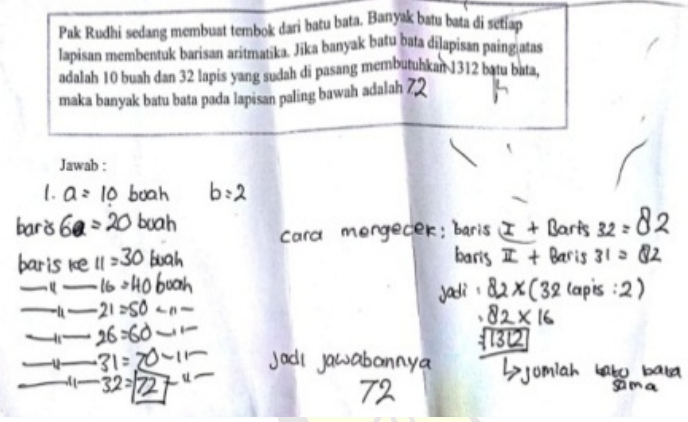

Gambar 1. Soal dan hasil pekerjaan siswa

Gambar 1 diatas merupakan salah satu contoh proses berpikir siswa dalam menyelesaikan masalah matematika mengenai materi barisan dan deret aritmatika yang telah diketahui bahwa lapisan paling atas 10 buah sebagai suku pertama dan lapisan yang sudah dipasang 32 lapis sebagai Sn adalah proses berpikir komputasional karena siswa tersebut kurang mampu menyatakan apa yang diketahui dalam soal, tidak mampu menyatakan apa yang ditanya dalam soal, tidak membuat rencana penyelesaian dengan lengkap, tidak mampu menyatakan langkah- langkah yang ditempuh dalam menyelesaikan soal dengan menggunakan konsep yang pernah pelajari, dan tidak mampu memeriksa kebenaran atau mengoreksi kesalahan dari setiap langkah sehingga siswa mengerjakan soal dengan tidak menggunakan konsep tetapi mengandalan intuisi. Jawaban dari soal tersebut adalah 72 dan jawaban siswa tersebut benar.

Beberapa penelitian yang telah dilakukan sebelumnya. Penelitian oleh Savitri \& Rahaju (2017) menunjukkan hasil bahwa siswa berkemampuan matematika tinggi dalam mengerjakan soal cerita program linear menggunakan proses berpikir konseptual, siswa berkemampuan matematika sedang dalam mengerjakan soal cerita program linear menggunakan proses berpikir semikonseptual, sedangkan siswa berkemampuan matematika rendah dalam mengerjakan soal cerita program linear menggunakan proses berpikir komputasional.

Mengingat arti pentingnya proses berpikir siswa dan fakta yang telah dilakukan bahwa proses berpikir siswa dalam menyelesaikan masalah masih kurang pada materi barisan dan deret aritmatika, menjadi dasar dilakukan penelitian. Peneliti tertarik untuk meneliti sejauh mana proses berpikir siswa dalam menyelesaikan masalah barisan dan deret aritmatika. Penelitian ini dilakukan di SMA Negeri 1 Ambarawa, karena sekolah tersebut merupakan sekolah favorit yang ada di daerah tersebut. Oleh karena itu, penelitian ini akan dilakukan di SMA Negeri 1 Ambarawa dengan judul Proses Berpikir Siswa Dalam Menyelesaikan Masalah Barisan dan Deret Aritmatika. Penelitian ini diharapkan dapat memberikan data yang relevan bagi penelitian selanjutnya. Data tersebut dapat menjadi dasar 
dalam refleksi guru menanamkan proses berpikir siswa dalam menyelesaikan masalah.

\section{Metode Penelitian}

Jenis penelitian ini adalah deskriptif kualitatif. Subjek dalam penelitian ini 3 siswa kelas XII SMA Negeri 1 Ambarawa tahun pelajaran 2018/2019. Subjek dalam penelitian ini terdiri dari FHA yang dikategorikan sebagai subjek kemampuan tinggi, AK yang dikategorikan sebagai subjek kemampuan sedang, dan WDR yang dikategorikan sebagai subjek kemampuan rendah. Pemilihan subjek siswa ditentukan dengan menggunakan purposive sampling, yakni teknik penentuan sampel dengan pertimbangan tertentu. Adapun pertimbangan tersebut antara lain: (1) nilai siswa pada saat ulangan saat materi barisan dan deret aritmatika (2) hasil jawaban siswa dari tes yang diberikan oleh penelitian, dan (3) merupakan hasil diskusi dan rekomendasi dari guru pengampu matematika. Teknik pengumpulan data dengan metode tes, wawancara, dan dokumentasi. Instrumen utama dalam penelitian ini adalah peneliti sendiri dan instrumen bantu yaitu pedoman wawancara, alat rekam, dan tes yang terdiri dari 2 nomor soal tes tentang barisan dan deret aritmatika. Indikator proses berpikir yang digunakan dalam penelitian ini adalah proses berpikir menurut Zuhri (2008) yang dapat dilihat pada Tabel 1 berikut.

Tabel 1. Indikator Proses Berpikir

\begin{tabular}{lc}
\hline Proses Berpikir & \multicolumn{2}{c}{ Indikator } \\
\hline Konseptual & - Mampu mengungkapkan \\
& dengan kalimat sendiri \\
& tentang hal yang \\
& diketahui dalam soal \\
& - Mampu mengungkapkan \\
& dengan kalimat sendiri \\
\hline
\end{tabular}

tentang hal yang ditanya dalam soal

- Mampu menjelaskan ide penyelesaian masalah dengan jelas

- Dalam menjawab soal cenderung menggunakan konsep yang sudah dipelajari

- Mampu mengungkapkan langkah-langkah yang ditempuh dalam menyelesaikan soal

\begin{tabular}{lll}
\hline Semikonseptual & $\begin{array}{l}\text { Kurang } \\
\text { mengungkapkan dengan }\end{array}$ \\
& kalimat sendiri tentang \\
& hal yang diketahui dalam \\
& soal
\end{tabular}

- Kurang mampu mengungkapkan dengan kalimat sendiri tentag hal yang ditanyakan dalam soal

- Kurang mampu menjelaskan ide penyelesaian dengan jelas

- Dalam menjawab soal cenderung menggunakan konsep yang sudah dipelajari walaupun tidak lengkap

- Tidak sepenuhnya mengungkapkan langkahlangkah yang ditempuh dalam menyelesaikan soal

- Tidak mampu mengungkapkan dengan kalimat sendiri tentang hal yang diketahui dalam soal

- Tidak mampu mengungkapkan apa yang ditanya dalam soal

- Tidak mampu menjelaskan ide penyelesaian masalah dengan jelas

- Dalam menjawab soal cenderung lepas dari 


\begin{tabular}{|c|}
\hline $\begin{array}{l}\text { konsep yang sudah } \\
\text { dipelajari } \\
\text { - Tidak mampu } \\
\text { mengungkapkan langkah- } \\
\text { langkah yang ditempuh } \\
\text { dalam menyelesaikan soal }\end{array}$ \\
\hline
\end{tabular}

\section{Hasil Penelitian dan Pembahasan}

\section{Hasil}

Hasil penelitian menunjukkan bahwa dalam menyelesaikan soal nomor 1 materi barisan aritmatika semua subjek menggunakan proses berpikir konseptual sedangkan dalam menyelesaikan soal nomor 2 materi deret aritmatika subjek tinggi menggunakan proses berpikir konseptual dan subjek sedang dan rendah menggunakan proses berpikir semikonseptual. Berikut merupakan hasil analisis proses berpikir dalam menyelesaikan masalah barisan dan deret aritmatika dapat dilihat pada Tabel 2 berikut.

Tabel 2. Daftar Nama Subjek Penelitian

\begin{tabular}{lccc}
\hline \multirow{2}{*}{$\begin{array}{c}\text { Materi } \\
\text { soal }\end{array}$} & $\begin{array}{c}\text { Konsept } \\
\text { ual }\end{array}$ & $\begin{array}{c}\text { Semikon } \\
\text { septual }\end{array}$ & $\begin{array}{c}\text { Komputa } \\
\text { sional }\end{array}$ \\
\hline $\begin{array}{l}\text { Nomor } \\
\text { (barisan }\end{array}$ & $\begin{array}{c}\text { FHA, } \\
\text { AK, dan }\end{array}$ & X & X \\
aritmatika) & WDR & & \\
\hline $\begin{array}{l}\text { Nomor } 2 \\
\text { (deret }\end{array}$ & FHA & AK dan & \\
aritmatika) & & WDR & $\mathrm{X}$ \\
\hline
\end{tabular}

Keterangan

FHA : Subjek kategori tinggi

AK : Subjek kategori sedang

WDR : Subjek kategori rendah

\section{Pembahasan}

\section{Soal No 1 (Barisan Aritmatika)}

Hasil analisis subjek soal nomor 1 berdasarkan kategori tinggi, sedang, dan rendah pada soal tes penyelesaian masalah barisan dan deret aritmatika pada tabel menunjukkan bahwa:

a. Subjek kemampuan tinggi (FHA)

Berikut merupakan deskripsi proses berpikir berdasarkan hasil pekerjaan tertulis dan wawancara subjek FHA. Subjek FHA mampu menyebutkan apa yang diketahui dalam soal dengan kalimatnya sendiri yaitu menghitung satu persatu taman bunga kemudian menghitung kembali jumlah lembaran paving untuk setiap taman tersebut. Selanjutnya, FHA juga dapat menyebutkan hal yang ditanyakan pada soal dan dapat merencanakan penyelesaian pada masalah taman bunga tersebut. Rumus yang digunakan sudah benar yaitu $U_{n}=a+$ $(n-1) b$. Langkah pertama yang dia tentukan adalah mencari a (suku pertama) dan beda (b) dari gambar pada soal. Selanjutnya, menghitung banyak suku pada taman bunga ke 100. Berdasarkan hasil tersebut, nampak bahwa subjek dapat menggunakan konsep yang telah diajarkan. Hasil pekerjaan subjek FHA dapat dilihat pada Gambar 1.

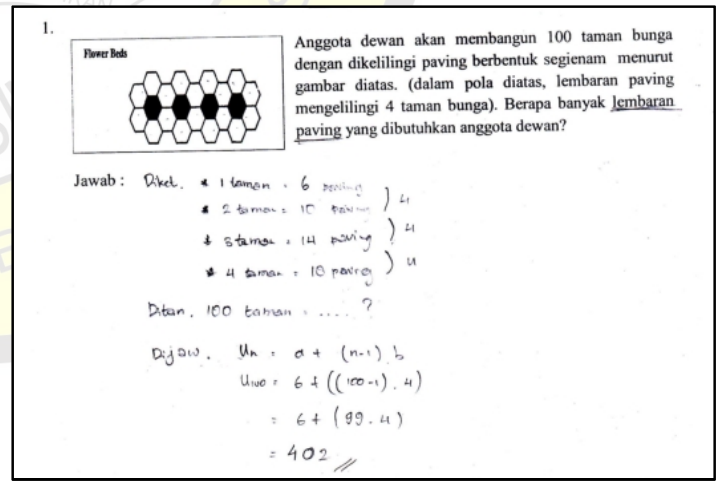

Gambar 1. Hasil Pekerjaan Subjek FHA

b. Subjek kemampuan sedang (AK)

Berikut merupakan deskripsi proses berpikir berdasarkan hasil pekerjaan tertulis dan wawancara subjek AK. Subjek AK kurang mampu menyebutkan apa yang diketahui dalam soal dengan kalimatnya 
sendiri yaitu hanya menyebutkan $a=6$ dan $\mathrm{b}=4$ tanpa diberi kata-kata apapun namun saat dilakukan wawancara subjek dapat menjelaskan apa yang diketahui dalam soal. Selanjutnya, AK juga kurang dapat menyebutkan hal yang ditanyakan pada soal namun memahami tentang hal yang ditanyakan pada soal nomor 1 yaitu $U_{1}$. Rencanakan penyelesaian yang disusun oleh subjek AK sudah benar yaitu mencari suku pertama dahulu kemudian mencari bedanya. Rumus yang digunakan sudah benar yaitu $U_{n}=a+(n-1) b$. Berdasarkan hasil tersebut, nampak bahwa subjek dapat menggunakan konsep yang telah diajarkan. Hasil pekerjaan subjek AK dapat dilihat pada Gambar 2.

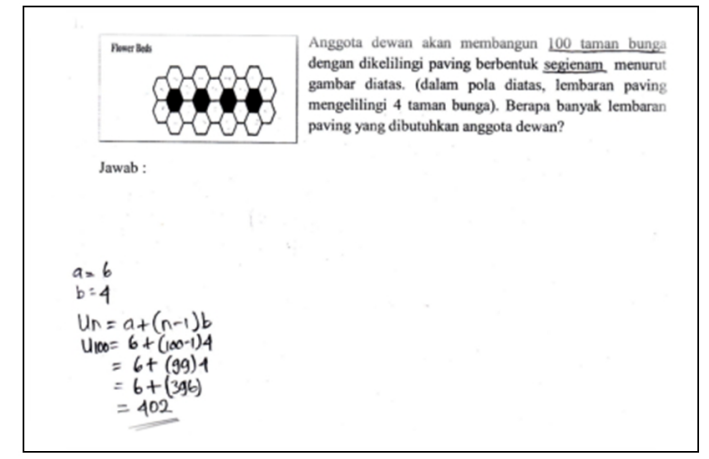

Gambar 2. Hasil Pekerjaan Subjek AK

c. Subjek kemampuan rendah (WDR)

Berikut merupakan deskripsi proses berpikir berdasarkan hasil pekerjaan tertulis dan wawancara subjek WDR dapat menjelaskan tentang hal yang diketahui dalam soal walaupun harus memahami soal berulang-ulang. Subjek dapat menyebutkan hal-hal apa saja yang diketahui dalam masalah, yaitu jumlah lembaran paving pada satu taman hingga empat taman bunga. Selanjutnya, WDR juga kurang dapat menyebutkan hal yang ditanyakan pada soal namun memahami tentang hal yang ditanyakan pada soal nomor 1 yaitu $U_{1}$.
Rencana penyelesaian yang disusun oleh subjek WDR sudah benar yaitu mencari suku pertama dahulu kemudian mencari bedanya. Rumus yang digunakan sudah benar yaitu $U_{n}=a+(n-1) b$. Berdasarkan hasil tersebut, nampak bahwa subjek dapat menggunakan konsep yang telah diajarkan. Hasil pekerjaan subjek AK dapat dilihat pada Gambar 3.

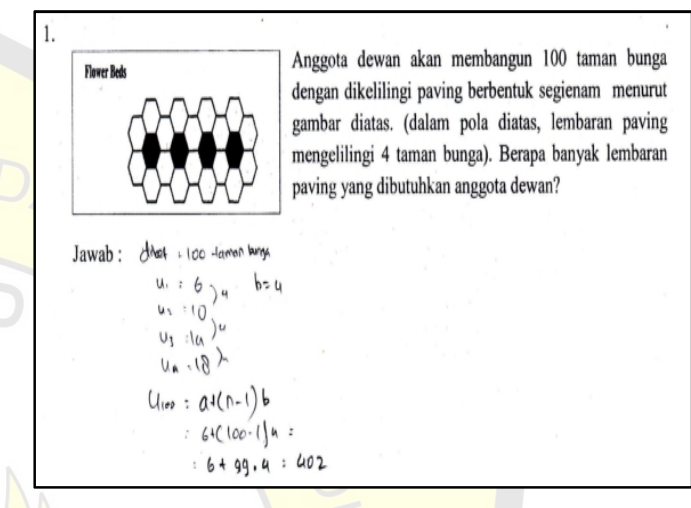

Gambar 3. Hasil Pekerjaan Subjek WDR

Berdasarkan hasil wawancara subjek tinggi, sedang, dan rendah pada soal nomor 1 materi barisan aritmatika, semua subjek dapat mengungkapkan hal-hal yang diketahui dan ditanya dalam soal, namun cara pengungkapannya berbeda-beda tetapi masih dalam makna yang sama. Subjek tinggi dan rendah mempunyai kesamaan dalam memahami hubungan antara apa yang diketahui dalam soal dan dapat merencanakan penyelesaian permasalahan, kemudian subjek dapat menggunakan konsep sesuai dengan apa yang dipelajari dan diperoleh jawaban yang benar namun pada subjek sedang meskipun telah menyusun rencana penyelesaian dengan benar, namun menggunakan cara yang lebih mudah yaitu langsung mencari suku pertama dan bedanya tanpa menghitung terlebih dahulu banyaknya lembaran paving pada satu taman dst. Hal tersebut 
membuktikan bahwa subjek sedang juga menggunakan konsep yang telah dipelajari, maka subjek tinggi, sedang, dan rendah dapat digolongkan dalam proses berpikir konseptual.

\section{Soal No 2 (Deret Aritmatika)}

Hasil analisis subjek soal nomor 2 berdasarkan kategori tinggi, sedang, dan rendah pada soal tes penyelesaian masalah barisan dan deret aritmatika pada tabel menunjukkan bahwa:

a. Subjek kemampuan tinggi (FHA)

Berikut merupakan deskripsi proses berpikir berdasarkan hasil pekerjaan tertulis dan wawancara subjek FHA. Subjek FHA mampu menyebutkan apa yang diketahui dalam soal dengan kalimatnya sendiri yaitu menghitung masing-masing jumlah kartu dari lantai satu sampai lantai tiga. Selanjutnya, FHA juga dapat menyebutkan hal yang ditanyakan pada soal dan dapat merencanakan penyelesaian pada masalah rumah kartu tersebut. Langkah yang dia tentukan adalah mencari a (suku pertama) dan beda (b) dari gambar pada soal. Selanjutnya, menghitung banyak kartu pada urutan ke-10 dan ke-62. Kemudian, menghitung jumlah kartu dengan tinggi lantai 10 dan 62 lantai. Berdasarkan hasil tersebut, nampak bahwa subjek dapat menggunakan konsep yang telah diajarkan. Hasil pekerjaan subjek AK dapat dilihat pada Gambar 4.

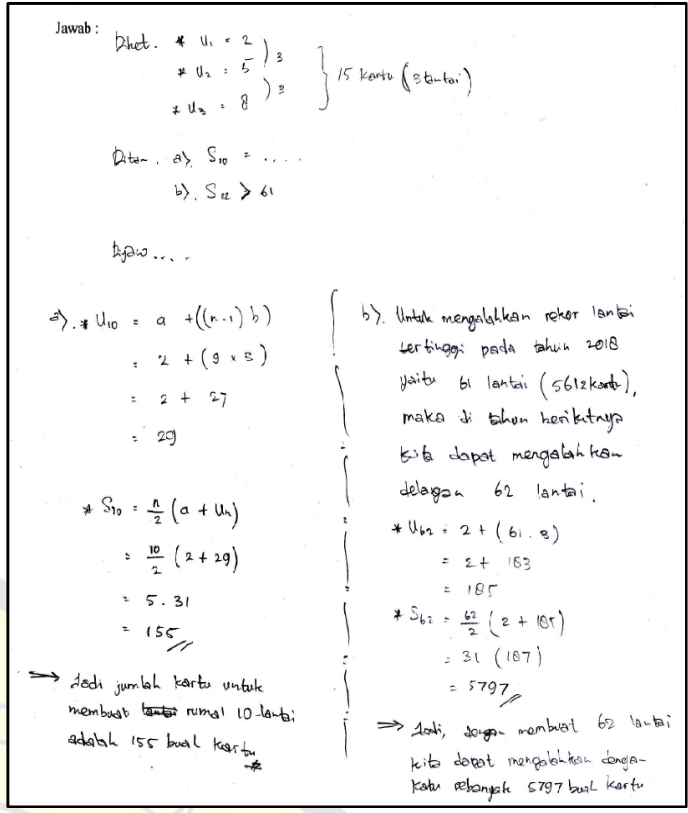

Gambar 4. Hasil Pekerjaan Subjek FHA

b. Subjek kemampuan sedang (AK)

Berikut merupakan deskripsi proses berpikir berdasarkan hasil pekerjaan tertulis dan wawancara subjek AK. Pada soal nomor 2a subjek AK dapat menjelaskan apa saja hal-hal yang diketahui pada soal, meskipun tidak menuliskan pada lembar jawab namun subjek memahami maksud dari soal karena pada saat dilakukan wawancara subjek dapat menjelaskan. Selanjutnya, subjek AK juga dapat mengetahui hal yang ditanyakan pada soal yaitu $S_{1}$. Subjek AK dapat merencanakan penyelesaian pada masalah rumah kartu tersebut tetapi menggunakan cara intuisi. Langkah yang dia tentukan adalah mengurutkan dari gambar soal sampai urutan ke-10 dengan beda 3. Selanjutnya pada soal nomor $2 \mathrm{~b}$ subjek AK tidak menuliskan apa yang diketahui dalam soal namun subjek dapat menjelaskan apa saja hal-hal yang diketahui pada soal karena pada saat dilakukan wawancara subjek dapat menjelaskan. Selanjutnya, subjek AK juga dapat mengetahui hal yang ditanyakan pada soal yaitu $S_{6}$. Subjek AK dapat merencanakan penyelesaian pada masalah rumah kartu tersebut yaitu menggunakan rumus deret aritmatika $\left(S_{n}\right)$. Subjek dapat 
menjelaskan langkah-langkah yang digunakan dalam menjawab soal. Hasil pekerjaan subjek AK dapat dilihat pada Gambar 5.

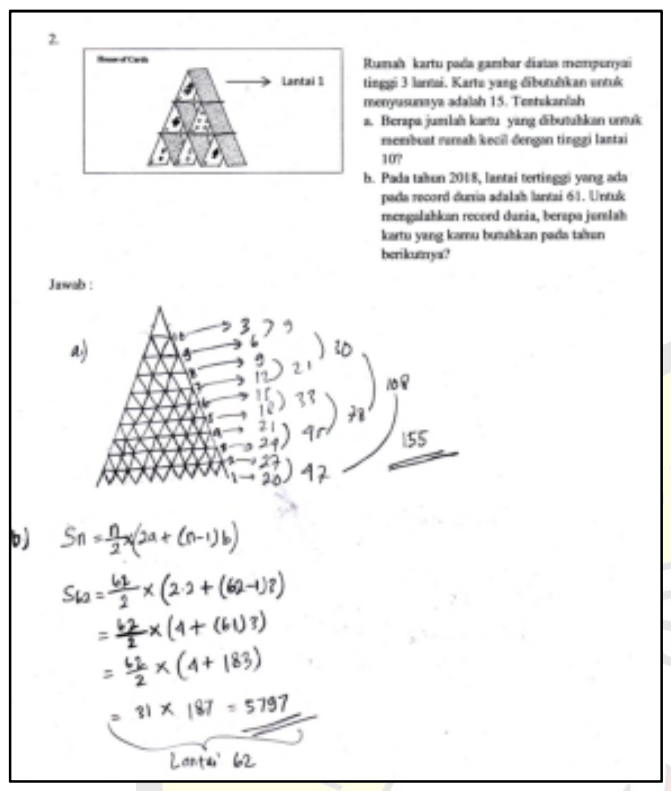

Gambar 5. Hasil Pekerjaan Subjek AK

c. Subjek kemampuan rendah (WDR)

Berikut merupakan deskripsi proses berpikir berdasarkan hasil pekerjaan tertulis dan wawancara subjek WDR. Subjek WDR mampu menyebutkan apa yang diketahui dalam soal dengan kalimatnya sendiri yaitu menghitung banyak kartu pada masingmasing lantai. Selanjutnya, WDR kurang dapat menyebutkan hal yang ditanyakan pada soal namun memahami tentang hal yang ditanyakan pada soal nomor 2 yaitu $S_{1}$ dan $S_{6}$ dan dapat merencanakan penyelesaian pada masalah rumah kartu tersebut. Langkah yang dia tentukan adalah mencari a (suku pertama) dan beda (b) dari gambar pada soal. Selanjutnya, menghitung jumlah kartu dengan tinggi lantai 10 dan 62 lantai dengan menggunakan rumus deret aritmatika. Namun untuk mencari $S_{1}$, subjek WDR menggunakan cara intuisi untuk mengecek jawaban. Berdasarkan hasil tersebut, nampak bahwa subjek dapat menggunakan konsep yang telah diajarkan. Hasil pekerjaan subjek WDR dapat dilihat pada Gambar 6.

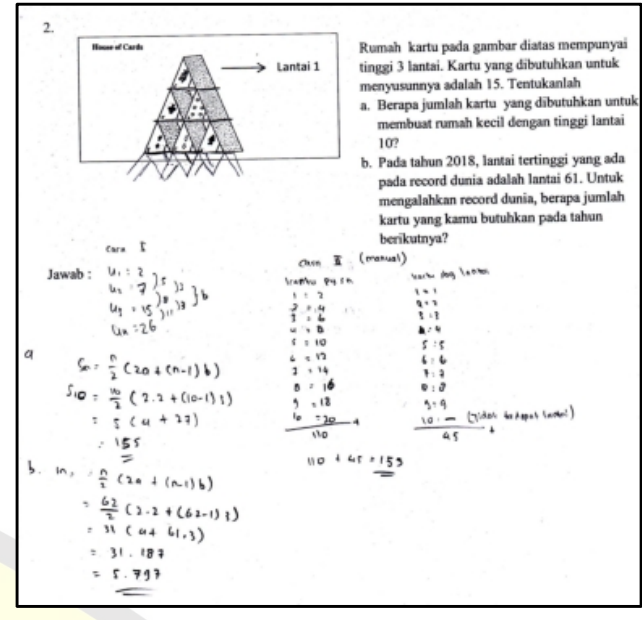

Gambar 6. Hasil Pekerjaan Subjek WDR

Berdasarkan hasil wawancara subjek tinggi, sedang, dan rendah pada soal nomor 2 materi deret aritmatika, semua subjek dapat mengungkapkan apa yang diketahui dan ditanya dalam soal. Subjek tinggi dan rendah memiliki kesamaan dalam memahami apa yang diketahui dalam soal dan dapat merencanakan penyelesaian permasalahan, namun pada langkah penyelesaian subjek tinggi sedikit berbeda tetapi masih dalam satu tujuan yaitu mencari jumlah kartu pada lantai 10 dan 62. Subjek tinggi terlebuh dahulu menghitung $U_{1}$ dan $U_{6}$ kemudian disubstitusikan ke dalam rumus $S_{n}$ sedangkan subjek sedang dan rendah langsung menghitung $S_{1}$ dan $S_{6}$. Subjek rendah mempunyai cara untuk mengecek apakah jawabannya salah atau benar dengan menggunakan cara intuisi. Subjek tinggi dan rendah dapat menggunakan konsep sesuai dengan apa yang dipelajari dan diperoleh jawaban yang benar meskipun serupa dengan subjek sedang juga menggunakan cara konsep tetapi juga menggunakan cara intuisi.

Hal tersebut membuktikan bahwa subjek tinggi menggunakan konsep yang telah dipelajari kemudian subjek rendah dan sedang dapat mengunakan 2 cara yaitu cara konsep 
dan cara intuisi. Berdasarkan hasil tersebut, subjek tinggi digolongkan dalam proses berpikir konseptual sedangkan subjek sedang dan rendah digolongkan dalam proses berpikir semikonseptual.

\section{Simpulan dan Saran}

\section{Simpulan}

Berdsarkan hasil analisis dan pembahasan, didapatkan bahwa dalam menyelesaikan soal nomor 1 materi barisan aritmatika semua subjek menggunakan proses berpikir konseptual sedangkan dalam menyelesaikan soal nomor 2 materi deret aritmatika subjek tinggi menggunakan proses berpikir konseptual dan subjek sedang dan rendah menggunakan proses berpikir semikonseptual.

\section{Saran}

Peneliti menyarankan kepada guru agar mampu mengetahui proses berpikir siswa karena dengan mengetahuinya guru mampu membantu siswa dalam mengerjakan masalah matematika. Pada saat siswa mengalami kesulitan pada langkah tertentu, guru dapat membantu siswa sehingga dalam mengerjakan soal matematika siswa dapat mengerjakan soal dengan benar dan sistematis.

\section{Daftar Pustaka}

Abdurrahman, M. (2003). Pendidikan Bagi Anak Berkesulitan Belajar. Jakarta: PT. RINEKA CIPTA.

Alwi, H. (2010). Kamus Besar Bahasa Indonesia. Jakarta: Balai Pustaka.

Beny, Kriswandani, \& Ratu Novisita. (2016). Analisis Proses Berpikir Dalam
Menyelesaikan Soal Geometri Ditinjau Dari Gaya Kognitif Field Independent Dan Field Dependent Pada Siswa Kelas VIII SMP Negeri 4 Boyolali. Universitas Kristen Satya Wacana Salatiga.

Eka, Kharisma. (2008). Proses berpikir siswa dalam menyelesaikan soal cerita di SMU Kelas X. Universitas negeri surabaya. Disertasi. Skripsi tidak dipublikasikan. Hudojo, Herman. (2003). Pengembangan Kurikulum dan Pembelajaran Matematika. Malang. Universitas Negeri Malang.

Jagom, Y.O. (2018). Proses Berpikir Siswa Dalam Menyelesaikan Soal Cerita Pada Pokok Bahasan Aritmatika Sosial.

Kalangi, Josep Bintang. (2015). Matematika Ekonomi dan Bisnis. Jakarta: Salemba Empat.

Khasanah, Ummi. (2015). Kesulitan Menyelesaikan Soal Cerita Matematika Pada Siswa Smp Negeri 1 Colomadu Tahun Pelajaran 2014/2015. Skripsi thesis, Universitas Muhammadiyah Surakarta.

Kusumawati, I. (2014). Identifikasi Proses Berpikir Siswa SMP dalam Menyelesaikan Masalah Membuktikan Dua Segitiga Kongkruen Berdasarkan Perbedaan Gender. Jurnal Ilmiah Pendidikan Matematika MATHEdunesa, vol 3, No. 3, h. 114-119.

Kuswana, W.S. (2013). Taksonomi Berpikir. Bandung: PT Remaja Rosdakarya.

Moleong, M.A. (1998). Metodologi Penelitian Kualitatif. PT Remaja Rosdakarya Bandung.

Prosiding, Seminar Nasional Etnomatnesia, h. 436-441.

Rizal, M., Budayasa, I.K., Lukito, A., dan Siswono, T.Y.E. (2012). Proses Berpikir 
Siswa SD Dalam Melakukan Estimasi

Masalah Berhitung Berdasarkan Jenis

Kelamin, Jurnal Ilmu Pendidikan, vol 18, No. 1, h. 48-57.

Savitri, I.R., dan Rahaju, E.B. (2017). Proses

Berpikir Siswa dalam Menyelesaikan

Soal Cerita Program Linear Ditinjau dari

Kemampuan Matematika. ", Jurnal

Ilmiah Pendidikan Matematika

MATHEdunesa, vol 6, No. 1, h. 114-120.

Siswono, Tatag Yuli Eko. (2002). Proses

Berpikir Siswa Dalam Pengajuan Soal.

Jurnal Nasional Matematika atau Pembelajarannya, Volume VIII, ISSN 0852-7792. Universitas Negeri Malang.H:44 - 50. Diakses tanggal 7 Agustus 2018 dari https://tatagyes.files.wordpress.com/200 9/11/paper02_berpikir2.pdf

Soejadi. (2000). Kiat Pendidikan Matematika di Indonesia. Jakarta : Dirjen Dikti Depdikbud.

Sugiyono, (2009). Metode Penelitian pendidikan (Pendekatan Kuantitatif, Kualitatif, dan R\&D). Alfabeta Bandung.

Sugiyono. (2010). Metode Penelitian Pendidikan(Pendekatan Kuantitatif, Kualitatif dan R\&D). Bandung: Alfabeta.

Sunaryo. (2011). Taksonomi Berpikir. Bandung: PT Remaja Rosidakarya.

Suryabrata, S. (1993). Psikologi Pendidikan. Jakarta: PT. Raja Grafindo Persada.

Zuhri, D. (2008). Proses Berpikir Kelas II SMP Negeri 16 Pekanbaru dalam Menyelesaikan Soal-soal Perbandingan Senilai dan Perbandingan Berbalik Nilai. Tesis. Surabaya: UNESA. 